\title{
COMPOSITE MEGACRYSTS AND MEGACRYST AGGREGATES FROM THE WILLIAMS KIMBERLITES, MONTANA, USA: MULTIPLE PRODUCTS OF MANTLE MELTS.
}

Hearn, B. Carter, Jr.

U.S. Geological Survey, 959 National Center, Reston VA 22092 USA.

The Williams kimberlites of Eocene age in north-central Montana contain megacrysts (size $>1 \mathrm{~cm}$ ) of olivine (mostly serpentinized), garnet (gar), phlogopite (phl), clinopyroxene $(c p x)$, and ilmenite (ilm) (in order of decreasing abundance), which are typical of the $\mathrm{Cr}$-poor suite of megacrysts from kimberlites world-wide. Also present are composite megacrysts (megacrysts with inclusions of generally 0.2 to $2 \mathrm{~mm}$ size) and rare megacrystalline aggregates (coarse-grained nodules with two or more phases or monomineralic clusters of grain size $>1 \mathrm{~cm}$ ), in which coexisting phases provide data to calculate temperature $(T)$ and pressure $(P)$ for the Eocene upper mantle.

Composite garnet megacrysts contain grains of one or more of the phases $c p x$, orthopyroxene (opx), ilm, phl, and calcite, and contain tiny rounded to elongate grains of spinel (sp), rutile (rut), or ilm. Elongate grains are probably exsolved; others could be primary inclusions or annealed exsolution grains. Composite garnet megacrysts have $\mathrm{Mg \# [}=100 \mathrm{Mg} /(\mathrm{Mg}+\mathrm{Fe})] 74-83, \mathrm{Cr}_{2} \mathrm{O}_{3}$ 0.15-3.39\% [\% = wt.\%], and $\mathrm{TiO}_{2}$ $0.05-1.35 \%$. These compositional ranges are similar to those for the mono-mineralic garnet megacryst population (McGee, 1986): Mg\# 68 to 88 (larger than in any other kimberlite), $\mathrm{Cr}_{2} \mathrm{O}_{3}$ 0-2.4 wt\%, and $\mathrm{TiO}_{2}$ 0-1.5\%.

Three composite cpx megacrysts contain primary inclusions of gar or phl of $>0.2 \mathrm{~mm}$ size. Other cpx megacrysts contain tiny $(<0.1 \mathrm{~mm})$, probably primary inclusions of subrounded, irregular, or euhedral $\mathrm{Mg}$-ilm or $\mathrm{FeCr} \mathrm{sp}$, and also contain tiny elongate to needle-shaped opx, Mg-ilm, Ti-magnetite (Timag), or sp, of probable exsolution origin. $\mathrm{Cpx}$ megacrysts have $\mathrm{Mg} \# 84-93, \mathrm{Cr}_{2} \mathrm{O}_{3} 0.03-0.57 \%$, and $\mathrm{Al}_{2} \mathrm{O}_{3}$ $0.47-3.30 \%$. Cores are generally unzoned, and thin intact rims show higher $\mathrm{MgO}$ and lower $\mathrm{FeO}$ and $\mathrm{Al}_{2} \mathrm{O}_{3} . \mathrm{CaO}, \mathrm{Na}_{2} \mathrm{O}$, and $\mathrm{Cr}_{2} \mathrm{O}_{3}$ can be either enriched or depleted in rims, implying that individual megacrysts were exposed to different late-stage fluids.

Six megacryst aggregates consist of gar $+c p x$, gar $+c p x+o l$, gar $+c p x+i l m$, gar $+c p x+p h l$, ilm + gar, and gar + phl + rut. The minerals lack strain features. Several aggregates contain fine-grained veins of Al-rich opx and cpx, Mg-Al sp, and serpentine or chlorite. One contains veins of Al-Ti cpx, Ti-amphibole, and serpentine. Garnet in the gar-phl-rut aggregate has $\mathrm{Mg \#}$ of 48 , suggesting a crustal origin. Garnets in the other five aggregates have $\mathrm{Mg} \# 73-80$ and $\mathrm{Cr}_{2} \mathrm{O}_{3} 0.04-0.81 \%$. $\mathrm{Ca}-\mathrm{Mg}-\mathrm{Fe}$ contents fall in the field of Williams gamet megacrysts (fig. 1), indicating that both could have similar deep source regions. Garnets in ilmenite-bearing assemblages tend to be more Fe-rich than in ilmenite-free assemblages. The megacryst and the aggregate garnet with lower $\mathrm{CaO}$ contents both have high $\mathrm{TiO}_{2}$ contents, similar to $\mathrm{CaO}-\mathrm{TiO}_{2}$ relations in Williams megacryst garnets.

Ilmenites in aggregates and composite megacrysts contain 6.9-13.1\% $\mathrm{MgO}$ and $0.3-2.0 \% \mathrm{Cr}_{2} \mathrm{O}_{3}$, ranges typical of ilmenite megacrysts and xenocrysts in kimberlites. Thus the aggregates may represent upper-mantle sources of ilmenites in kimberlite.

Most of the phlogopites $111.1-15.7 \% \mathrm{Al}_{2} \mathrm{O}_{3}, 0.7-4.7 \% \mathrm{TiO}_{2}, 0.1-1.1 \% \mathrm{Cr}_{2} \mathrm{O}_{3}$, $0-0.8 \% \mathrm{BaO}$, and $0.2-0.7 \% \mathrm{~F})$ in composite megacrysts and aggregates are similar in composition to primary phlogopites in peridotite xenoliths and to megacryst phlogopites. All are dissimilar to groundmass phlogopites in the host kimberlite, which are more Fe-rich, contain tetra-ferriphlogopite component, lower $\mathrm{Al}_{2} \mathrm{O}_{3}$, and lower $\mathrm{Cr}_{2} \mathrm{O}_{3}$.

Calculated T's of equilibration of composite garnet megacrysts are 940 to $1390^{\circ} \mathrm{C}$ by the Ellis and Green (1979) gar-Cpx method (EG79) or the Finnerty and Boyd (1986) Mg in cpx method (FB86) (assuming the presence of opx). Calculated 
T's for megacryst aggregates are 1045 to $1265^{\circ} \mathrm{C}$ by the same methods, and are within the $T$ range of composite garnet megacrysts. For five of the seven analyzed clinopyroxene megacrysts, $\mathrm{T}$ is low, 500-660 ${ }^{\circ} \mathrm{C}$ (FB86); $\mathrm{T}$ for one is $1130^{\circ} \mathrm{C}$ (FB86), and $T$ for one with coexisting garnet is $780^{\circ} \mathrm{C}$ (EG79). The lower $T$ clinopyroxenes contain ilm, Ti-mag, or sp inclusions and lack garnet, and thus may be from the more shallow spinel facies in the upper mantle. Calculated $P$ is $55 \mathrm{~kb}$ for one composite garnet megacryst by the Nickel and Green (1985) method based on Al in opx, and $45 \mathrm{~kb}$ for one aggregate by the Kohler and Brey (1990) method based on $\mathrm{CaO}$ in olivine. Projection of T's onto the geotherm estimated from Williams peridotite xenoliths (Fig. 2) implies that many of the aggregates and composite garnet megacrysts are from the $50-60 \mathrm{~kb}$ region of high T,P garnet peridotites.

Megacryst aggregates appear to be coarse-grained, pegmatitic products of melts in the lithospheric upper mantle, which crystallized in a range of moderate to high $T$ and $P$. The chemical similarity of aggregates and megacrysts suggests that the aggregates represent the multi-phase upper-mantle source rocks which were disaggregated to produce at least part of the suite of garnet, clinopyroxene, and ilmenite megacrysts and xenocrysts. The wide range of chemistry and of calculated or inferred $T$ and $P$ indicate that the composite megacrysts and megacryst aggregates crystallized from several separate melts, rather than constituting a related series of products from a single melt. Vein mineralogy in aggregates suggests access of $\mathrm{Fe}-, \mathrm{Al}-$, Ti-rich fluids in the gar + sp stability field, just prior to or during ascent of the kimberlite; such fluids or melts must have been somewhat different from the host kimberlite. The geochemical complexity is consistent with the complex history of depletion and enrichment of the Montana lithospheric upper mantle in Montana.

References:

Ellis, D.J., and Green, D.H. (1979) An experimental study of the effect of $\mathrm{Ca}$ upon garnet-clinopyroxene $\mathrm{Fe}-\mathrm{Mg}$ exchange equilibria. Contributions to Mineralogy and Petrology, 71, 13-22.

Finnerty, A.A., and Boyd, F.R. (1987) Thermometry for garnet peridotites: basis for the determination of thermal and compositional structure of the upper mantle. In P.H. Nixon, Ed., Mantle Xenoliths, p. 381-402, Wiley and Sons Ltd., London.

Hearn, B.C., Jr., and McGee, E.S. (1984) Garnet peridotites from Williams kimberlites, north-central Montana, USA. In J. Kornprobst, Ed., Kimberlites II: The Mantle and Crust-Mantle Relationships, p. 57-70, Elsevier, Amsterdam.

Kohler, T.P., and Brey, G.P. (1990) Calcium exchange between olivine and clinopyroxene calibrated as a geothermobarometer for natural peridotites from 2 to $60 \mathrm{~kb}$ with applications. Geochimica et Cosmochimica Acta, 54, 2375-2388.

McGee, E.S. (1986) Garnet megacrysts of the Williams diatremes, north-central Montana. American Mineralogist, 71, 674-681.

Nickel, K.G., and Green, D.H. (1985) Empirical geothermobarometry for garnet peridotites and implications for the nature of the lithosphere, kimberlites and diamonds. Earth and Planetary Science Letters, 73, 158-170. 




Fig. $1 \mathrm{Ca}-\mathrm{Mg}-\mathrm{Fe}$ composition ( $\mathrm{mol} \%$ ) of gar, $\mathrm{cpx}$, and ilm in composite megacrysts and megacryst aggregates; lines join coexisting phases; dashed-line = field of Williams garnet megacrysts from McGee (1986).

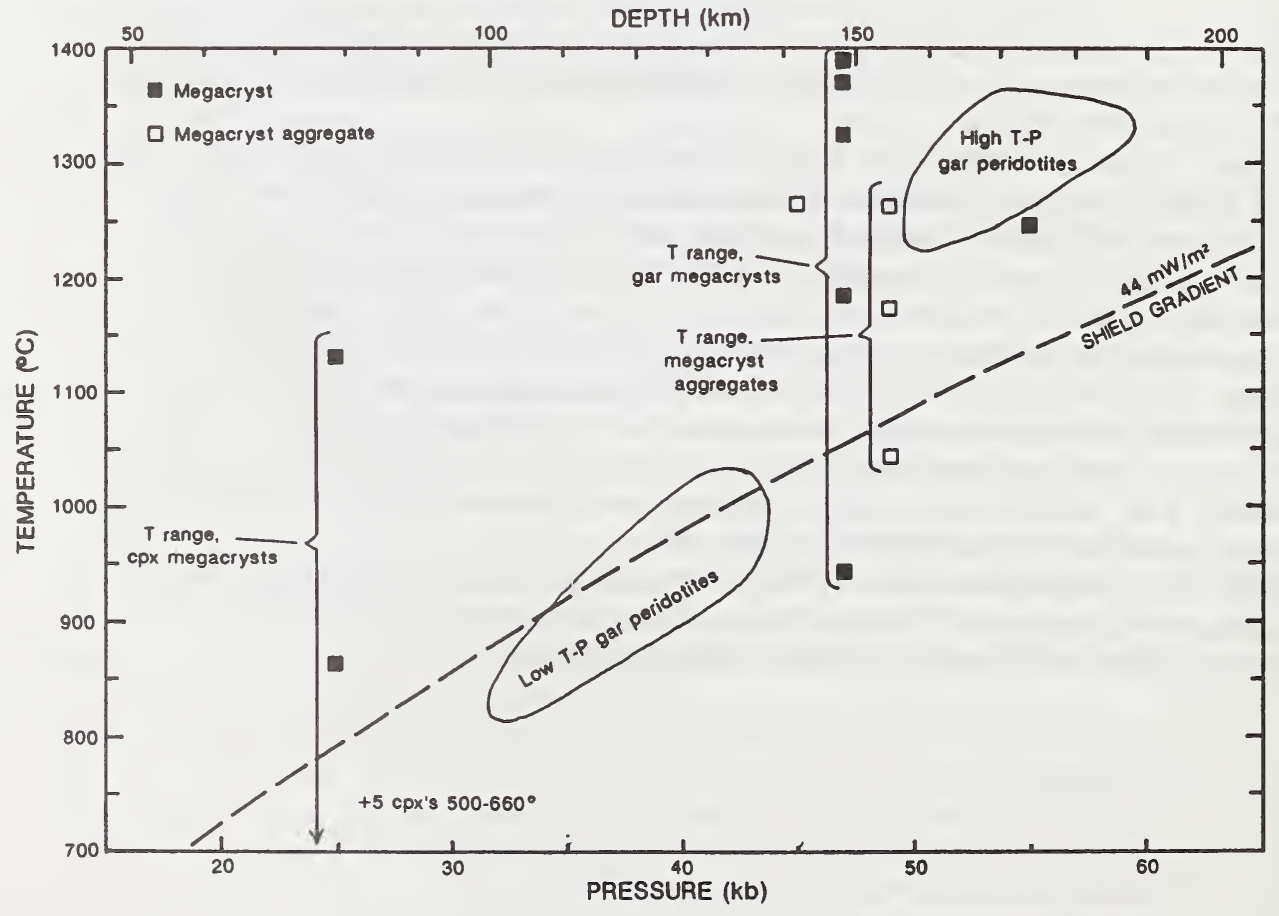

Fig. 2 Calculated T and ranges of T (by EG79 and FB86 methods) for megacryst aggregates and garnet megacrysts (arbitrarily plotted near $48 \mathrm{~kb}$, except two with calculated P), and cpx megacrysts (arbitrarily plotted near $25 \mathrm{~kb}$ ); fields of Williams garnet peridotites from Hearn and McGee (1984). 